\title{
Analysis on the Development Status of Art Derivatives in Museum
}

\author{
Jin Qiao \\ Huanghe Science and Technology College \\ Zhengzhou, China, 45006
}

\begin{abstract}
Through the analysis of conception, the paper has discussed the inevitability of museum's development, and further, based on the analysis of some data, has demonstrated the existing problems in the development of art derivatives in museum, thereby providing some constructive suggestions for the explanation of the development status of art derivatives in domestic museums.
\end{abstract}

\section{Keywords—-museum; art derivatives; development}

\section{INTRODUCTION}

Art derivatives refer to the objects derived from the things in original art works, which have been divided into two categories: one is the copies of original works, such as the engravings specially for collection and appreciation, emulational bronzes, jades and porcelains, etc.; the other one is to have the images or elements of art works printed or extracted on various common products so as to make them art derivatives with artistic characteristics which can not only achieve higher additional artistic value in sales but also publicize and promote the art culture.

\section{ORganizATION OF THE TEXT}

\section{A. Conception of derivatives with museum elements}

"Currently, there is no authoritative academic definition for the connotation of museum art derivatives which, however, usually refer to the outward-expanded conceptual creative merchandises centered by ideological spindle of the original works collected in museum. The purpose for such development and design is to allow consumers through merchandises to comprehend the connotation of art works and the creation idea of authorship, which enables the cultural connotation of cultural relics themselves to be connected and linked with the merchandises, creating the museum culture memory that can be brought home for collection.”. [1]

As mentioned in the book Art \& Economics - Analysis \& Cultural Policy written by Economist Bruno S.Frey, the establishment of a coffee house and restaurant along with a store full of beautiful art works in museum will definitely generate a lot of revenue, also taking the world famous Museum of Modern Art in New York as an example: 30\% of the Museum's revenue comes from publications and similar business activities, and from 1986 to 1988, the museums in

Fund project: 2013 Henan soft science research project The Research on Cultural Industry Development of Art Derivatives of Henan Museum, project number: 132400410358
America made a profit of nearly 301,000,000 U.S. dollars, accounting for $17.5 \%$ of the gross proceeds (inventory gains: $\$ 84,000,000$; restaurant earnings: $\$ 5,000,000$; other profits: $\$ 130,000,000$; and the rest $\$ 82,000,000$ is from the entrance fees). ${ }^{[2]}$ It can be learned from the above data that the art store has been one of the most important sources of museum's revenue.

\section{B. Inevitability of museum's development of art derivatives}

1) Alleviation of museum's budget issue

The museum operation mechanism in China is different from that in foreign countries. Most museums in China are dependent on state and local government funding while art institutions assume the responsibility of art popularization and promotion. However, most museums in foreign countries are operated by individuals or funded by personal donations, especially after the financial crisis, the British government cut down public expenses in the implementation of financial budget, such as museums, theaters, libraries and other cultural institutions. The lack of funds hindered the normal operation of museum and other cultural institutions, therefore, MacGregor Curator of British Museum, Celta - Curator of Tate Gallery, Haidt Turner - Director of National Theatre and other highly influential figures in British culture circles sat on the steps of British Museum holding signs to ask the government for funding. They also took some measures, like placing donation box at the door of some free museums, in hope of catching "a big fish”. Whereas, it appeared to have little effect: it not only could not receive much money but also would ruin the visitor's mood. For the art institution, no matter run by the state or operated by individual, there is always a problem in 'how to make it profitable'.

In 1950s, the cause of China's museum was based on the planned economic system which took public ownership as foundation, highly bureaucratized, fully embodying the state's ideology. At this time, state financial appropriation had been the main source of the operating funds for the museum all along and the state took care of everything. Especially after the reform and opening up, the state has been intensely aware of the public property of the museum, attaching greater importance to the museum culture development, increasing the appropriated funds and carrying out the free opening-door policy. However, in the long run, since the museum is fully funded by government, once the economy turns bad, the museum undoubtedly will suffer from the shortage of funds. 
Thus, to be prepared for danger in times of safety, the museum shall consider more capital source channels.

The cultural relics store in museum occupies an important position in the business. The merchandises sold in the museum possess excellent quality. Besides, against the historical context of pursuing commodity packaging with art, the artistic value of cultural relics store itself has been added to each merchandise and a basic understanding of merchandise's background can be achieved via salesperson's explanation and education, which is quite different in nature from the cultural relics bought in places other than the museum. The museums in Europe and the United States use the surplus income of cultural relics stores to finance the museums themselves so as to have enough funds for running and hiring professional talents. As a matter of fact, this profit-making conduct in non-profit undertakings has its reasonability and expediency.

\section{2) Cultural industrialization of new museums}

Cultural industry refers to the industry which specializes in production, sales and service of cultural products to serve for society. The museum is also formed according to the social division of labor system, with the enterprise of input and output, and is engaged in the production of cultural products to serve for society. Therefore, in a broad sense, the museum also belongs to cultural industry. The European Commission of Culture Industry also considers the museum as "production and sales system of cultural and arts activities”.

Since the 1980s, the concept of New Museology began to rise. The new museum movement reformed the past conservative traditional mode of operation, thus the museum is no longer just limited to play the roles of things'collection, maintain and display, but stresses the future of the relationship between the museum and the social, environmental and regional development in the national and even international network. Museum's focus, did not regard the traditional functions as the main any longer, such as collection, research, preservation, and display, but turns to the content of local social concern. ${ }^{[3]}$

In conclusion, the rise of the new museology has made the museum produce great shift in the management subject, target and strategy, which has prompted the museum to strengthen its links with the masses and the market, and prompted the museum to realize their own subject status of the important cultural resources. All of these make the current museum have to seriously consider the problem of industrialization, so the industrialization is a new choice of the museum under the new social, economic and cultural environment. The industrialization will not only improve the living conditions of the museum, but also deepen the museum cultural function to spread knowledge. The old system has been very weak in the new environment, and even endangers the museum's normal function and survival. But the industrialization exactly adds some new power system for the museum, and the source of the power system is just the needs of the market and the masses. The emergence of New Museology not only in theory provides the justification and necessity of the industrialization of museum, but also from the actual operation strategy and the case analysis, discovers the museum could produce benefits, and finds the future developmental direction of the museum.

\section{Insufficient congenital conditions of domestic museum derivatives}

Art institutions abroad has went fairly early in the field of art derivatives, and has been leading in the domestic market. Guggenheim Museum's international brands, cultural classics, and successful operation has won interest and participation of international consortium and giants of finance, transportation, and media, and thus has formed some fixed sponsored groups which also maintain and improve their popularity in the sponsorship. Rich return has effectively resolved the problem of funding, so that "the Guggenheim mode" has formed a virtuous circle.However,the development of Chinese museum derivatives is rather late, and there are many deficiencies, such as single products, lack of design talents, lack of brand consciousness, etc.

\section{1) Single product variety}

Art Derivatives developed by Taipei creativity is various, and the form is novel, "the national treasure derivatives benefits the Taipei museum with a profit of one hundred million yuan." ${ }^{[4]}$ His great success has set a good example for many museums. In 2010, Shanghai Expo of Taipei Twins cultural creativity industry, with the slogan of "make creativity express the ideal", exhibited creative art derivatives of Taipei Palace Museum, which has won a good reputation. Guo Yicheng, in charge of the authorized creation team of Taipei Palace Museum said: “Actually, in foreign countries, all the art galleries and museums are nearly equipped with their own art shop. Derivatives have extended to clothing, toys, home decor, audio books, online games, food and beverage and other various fields of people's daily life, becoming the economic backbone of the museum's revenue." In a word briefly, " whatever you can think of are sold here". The Taipei Palace Museum is a place, where not only whatever you think of can be sold, but also whatever you do not think of can be sold.

Shanghai Museum can be described as the leader of the development of domestic derivatives, and is exemplary in the aspects of design and application of product strategy. Since 1996, it has successfully developed more than 1600 kinds of cultural goods, and its annual sales has climbed to \$25 million, even over the ticket sales. In the Exhibition of Ancient Egyptian Treasures, the sponsor set up points of purchase of propaganda material at the entrance and exhibition hall, and souvenir mold are provided by the Egyptian side, and authorized to sell only during the exhibition, which attracted many visitors to buy, so a lot of gifts were sold out.In the "National Treasure Exhibition of Painting and Calligraphy of Jin, Tang, Song,and Yuan”, there are three cultural goods directly derived from the exhibition: special issue joint planned by Shanghai Museum and the "Heritage Zone" magazine, priced at 15 yuan a, with a total sales of 50000 copies, and the income of 750, 000 yuan; VCD of the introduction of 71 pieces of calligraphy and painting exhibitions, unit price of 40 yuan, with a total sales of 5,000 pieces, and the income of 200,000 yuan;a printed 72 pieces of calligraphy and painting album, 6000 yuan of one, printed 2500 copies, 500 copies sent to the Palace Museum and the Liaoning Provincial Museum, the remaining 1500 copies all sold out.” ${ }^{[5]}$ 
Today Luo Yi, the executive director of art museum design museum, mentioned the development of museum of art derivatives in recent years in the Artron interview. "according to a survey of National Heritage Board,domestic museums which the value of derivative value are over 5 million yuan only has two museums: Beijing Palace Museum and Shanghai Museum, which can reflect the part of the present situation of the domestic art derivatives,compared with Taipei Palace Museum's one year derivatives turnover of around NT \$300 million,annual sales of 300 million to 500 million yuan of British TATE museum store, and annual sales of 500 million yuan to 700 million yuan of the US Metropolitan museum stores. Although the system, standards, and scale of art stores of domestic museums and art galleries are in an early stage, the development of art derivatives is on the rise, from the market capacity and the growth space, especially with the progress and improvement of policy environment and market recognition.

China's art derivatives are just starting out,thus its design, research and development, management, and sales is not very standardized. Our art derivatives market exists the following shortcomings: on the one hand is that the form of folk art derivatives is relatively single,and most are the simple copying or printed on some commodities, which can not combine with commodity well.Art derivatives of any of the museums that tourists visit are the same, and the only difference is that the logo is different. The designed products has no no novelty, and at the same time the product is single, generally cup, mobile phone chain,pen case,and ornaments. In fact, we can develop it to many aspects of articles of daily use.

\section{2) Lack of design talents}

The development of folk art derivatives are mostly that folk traders simply copy the ready-made images on the plates, cups and other commodities, or copy a small works,no special creative design,so that consumers see the similar derivatives, and shrink back at the sight of derivatives. Chinese art derivatives market development still has not a complete standard, and art college has not set up corresponding courses of the systematic training , design and development of folk art, and is lack of derivatives industry's design, development, marketing management and other knowledge which are necessary for products's development.

Design talents are extremely lacking, which leads to single design products that can't keep up with the aesthetic demand of the market,thus restricting the development of art derivatives. At the same time, the market is also lack of creative managers of promotion the cultural industry to carry out packaging, publicity and promotion and operations of art derivatives. These factors lead to the backwardness of art derivatives market

\section{3) Lack of brand consciousness}

"The regional comparative advantages of folk art must be combined with the regional cultural and economic development level, regional characteristic ans other index, thus can be converted into real advantages, becoming a catalyst for accelerating the development of regional productivity”. The psychology of museum visitors'buying art derivatives, on the one hand, is to deepen impression of museums, and the trip to the region, on the other hand, is to the uniqueness of art derivatives. Associate professor of Academy of Fine Arts of Tsinghua University, Chen Nan said. "after visiting the museum, you want to buy a derivative with the museum symbol or collection elements, that is because you have produced identity and feelings after you experience.” The art derivatives have a special symbol of the library and this region, which is unique. Therefore, developing art derivatives should increase our brand awareness.

In order to create famous cultural brand, and build industry highlight,one is to increase promotions, develop and occupy the market. The Second is to strength the linkage of brand and industry. The cultural development needs cultural brand. Without brand, the cultural industry will not be able to get pass of the market, and without industry, the brand also will not be able to expand the market share. only the linkage of brand and industry can transform the "advantage" of cultural products into the "advantage" of the industrial economic development,to furthest build cultural industry highlights.

\section{CONCLUSION}

The current domestic art derivatives development, promotion and operation have not formed normative system and standards, and also have no cultural brand awareness. Brand culture can endow the brand with rich cultural connotation and quality, and win customer loyalty, thus winning a stable market, and increasing the competitiveness of enterprises. If products are made carelessly, products of poor quality are not worth buying for customers. However, foreign art derivatives, on product strategy packaging, know the corresponding brand strategy design, brand promotion and packaging design, and its products of fine quality, pursue novel and creative packaging effect,which can achieve unexpected results.The development of domestic art derivatives should have brand awareness, and increase the product reputation, for brand awareness can guide the public well. At the same time, it should constantly update product development speed and aging, which has strong non-replication, so as not to be repeated on the market and roughly copied. Therefore, it can provide strong guarantee for brand's continuously extension to improve the domestic art derivatives market environment, establish famous brand effect,and increase market competitiveness.

\section{NOTES}

${ }^{[1]}$ Ma Lin, Thoughts on the Development of Art Derivatives in Museum Store, Visual Arts, Jun. 2011, Page 58.

${ }^{[2]}$ Written by Bruno S.Frey and translated by Cai Yizhen and Lin Xiuling, Art \& Economics - Analysis \& Cultural Policy, Taipei, Art and Collection, 2003.

${ }^{[3]}$ Harrison.J.D., Ideas of Museums in the 1990's, Museum Management and Curatorship, 1993,13(2).pp.160-176.

${ }^{[4]}$ China Daily Liaoning Office, Derivatives Making Ancient Museum Art Vigorous -Three Reports of Liaoning "Expo" Series, China Daily website, June 12, 2011, http://www.chinadaily.com.cn/dfpd/ln/bwzg/201106/12/content_12678917.htm.

${ }^{[5]}$ Sun Qin'an, Shanghai Urban Culture: the Integration of Tourism Culture and Academic Exchange, Exploration and Contending, 2007, Issue 7, Page 14.

\section{REFERENCES}

[1] Huang Lei, The Foreign Cultural Exchange Work of Hunan Provincial Museum Reaching a New Stage [J], Chinese Cultural Relics Newspaper, 2007. 
[2] Ma Lin, The Thinking of Museum Shops'Art Derivatives Development [J], New Visual Art, 2011.

[3] Li Jinsheng, The First Discussion of the Problem of Industrialization of the Museum [D], Jinan: Shangdong University, 2008.

[4] Huang Hai, The New Trend of Museum Culture Visual Identity Design [J], Art Panorama, 2010.

[5] Zheng Yi, The Research of Museum Educational Activities [D], Shanghai: Shanghai Fudan University, 2012.

[6] Dai Anle, The Research of Museum Resources of Tourism Development [D], Tianjin: Tianjin University of Commerce, 2012. 